PENGARUH MODAL KERJA TERHADAP RETURN SAHAM

\title{
(studi kasus Perusahaan Tekstil Dan Garment Yang Terdaftar Di Bursa Efek Indonesia(Bei) Tahun 2010-2016 )
}

\author{
Windisari Tosampe ${ }^{1}$, H. Mustafa Muhani ${ }^{2}$, Asriany ${ }^{3}$ \\ Email : ${ }^{1}$ ) Windisari@stiem.ac.id \\ ${ }^{1,2,3}$ )Prodi Manajemen, Sekolah Tinggi Ilmu Ekonomi Muhammadiyah Palopo
}

\begin{abstract}
Abstrak
Penelitian ini bertujuan untuk mengetahui pengaruh modal kerja terhadap return saham pada perusahaan tekstil dan garment yang terdaftar di Bursa Efek Indonesia(BEI) tahun 20102016.Teknik sampel yang dijadikan sampel adalahn purposive samplingdiperoleh sebanyak 18 perusahaan yang dijadikan sampel dari total 12 perusahaan. Metode pengelolaan data yang digunakan adalah uji statistik deskriptif, uji asumsi klasik normalis, analsis regresi sederhana. Hasil penelitian ini menunjukkan bahwa modal berpengaruh signifikan terhadap return saham. Hal tersebut ditunjukkan dengan nilai signifikan sebesar 0,094<0,05.
\end{abstract}

Kata kunci : Return Saham, Modal Kerja

\section{PENDAHULUAN}

Tekstil dan garment Industri tekstil dan garment saat ini menjadi industri strategis bagi perekonomian Indonesia mengingat Indonesia memiliki 250 juta penduduk. Bahkan, industri ini bagian sektor manufaktur terbesar ketiga di Indonesia dan menjadi salah satu sektor yang paling banyak menyerap tenagakerja. Ekspor tekstil dan produk tekstil Indonesia mencapai US\$12,4 miliar pada tahun 2017, melebihi target dari Asosiasi Pertekstilan Indonesia (API) sebesar US $\$ 11,8$ miliar. Pemerintah sendiri bahkan menargetkan pertumbuhan ekspor di 2019 tumbuh menjadi US\$15 miliar. Permintaan tekstil yang tinggi di Asia Tenggara dan Timur Tengah menjadi faktor yang menentukan untuk mencapai target tersebut. Keputusan investasi merupakan salah satu hal paling penting yang dihadapi investor, keputusan investasi bagi seorang investor menyangkut masa akan datang yang mengandung ketidakpastian, atau mengandung unsur risiko bagi investor. Keinginan mendapatkan keuntungan merupakan suatu harapan bagi semua investor. Semakin tinggi risiko (risk)yang dihadapi seorang investor, semakin tinggi pula harapan investor untuk mendapat keuntungan (expected return). Pendapatan (Return)merupakan salah satu faktor yang dapat mempengaruhi investor dalam menanamkan modalnya. Return total dapat diperoleh dengan menjumlahkan yield dan capital gain (loss), di mana yield merupakan komponen return yang mencerminkan aliran kas atau pendapatan yang diperoleh secara periodik dari suatu investasi. Sedangkan capital gain (loss) merupakan kenaikan (penurunan) harga suatu surat berharga, yang bisa memberikan keuntungan (kerugian) bagi Investor

Modal kerja merupakan masalah utama yang akan menunjang kegiatan operasional perusahaan dalam rangka mencapai tujuannya. Kegiatan operasi perusahaan dapat digambarkan pada pengelolaan modal kerja. Modal kerja adalah investasi perusahaan jangka pendek seperti kas, surat berharga, piutang dan inventori atau seluruh aktiva lancar. Mengingat pentingnya modal kerja manager keuangan harus dapat merencanakan dengan baik besarnya jumlah modal kerja yang tepat dan sesuai dengan kebutuhan perusahaan, karena jika terjadi kelebihan atau kekurangan dan hal ini akan mempengaruhi tingkat profitabilitas perusahaan (Sarbapriya 2012).

Expected return dapat diperoleh dengan menggunakan single factor model yang biasa 
disebut dengan Capital Asset Pricing Model (CAPM) dan model tiga faktor yang diajukan oleh Fama dan French. CAPM menjelaskan keseimbangan pasar antara tingkat risiko yang sistematis dan tingkat keuntungan yang disyaratkan sekuritas portofolio. Dengan kata lain tujuan utama penggunaan CAPM adalah untuk menentukan tingkat keuntungan minimum yang disyaratkan dari suatu investasi. Keseimbangan pasar menurut kriteria markowitz menegaskan dua hal; (i) hubungan positif antara expected return $\mathrm{E}(\mathrm{r})$ dan Beta, (ii) Beta sebagai pengukur risiko tunggal, sebagai penjelas adanya perbedaan $\mathrm{E}(\mathrm{r})$ antar saham (cross section), artinya kita dapat menggunakan beta untuk mengetahui risiko serta untuk mengetahui E(r) suatu saham. Return atau tingkat keuntungan dari investasi merupakan hal yang penting bagi pemodal. Bagi para pemodal return merupakan tujuan dalam berinvestasi, karena alasan utama orang berinvestasi adalah untuk memperoleh keuntungan. Return yang diharapkan investor dari investasi yang dilakukannya merupakan kompensasi atas biaya kesempatan (opportunity cost) dan risiko penurunan daya beli akibat adanya pengaruh inflasi. Sehingga return akan sangat krusial bagi para pemodal dalam melakukan investasinya.

Berdasarkan latar belakang masalah tersebut, maka rumusan masalah dari penelitian ini yaitu : Apakah terdapat pengaruh modal saham terhadap return saham pada Perusahaan Tekstil Dan Garment Yang Terdaftar Di Bursa Efek Indonesia(BEI) Tahun 2010-2016?"

\section{METODE PENELITIAN}

Tempat dilakukannya penelitian ini yaitu pada Bursa Efek Indonesia melalui situs resmi yang diakses secara online di http://www.idx.co.id. Penelitian dilakukan pada 2010-2016.

Data yang digunakan dalam penelitian ini adalah berupa rasio-rasio laporan keuangan dari laporan keuangan yang terbit setiap akhir periode laporan keuangan pada perusahaantelekomunikasiyang terdaftardi bursa efek Indonesia untuk periode 2010-2016. http://www.idx.co.id. Dalam hal ini, peneliti tidak hadir langsung untuk melakukan penelitian, peneliti hanya mengumpulkan data melalui data yang telah tersedia atau dengan kata lain peneliti menggunakan metode dokumentasi secara online. Pengelolaan dan analisis data dalam penelitian ini menggunakan teknik statistik deskriptif dan analisis regresi berganda dimana dapat dirumuskan dalam persamaan sebagai berikut :

$$
\mathbf{Y}=\boldsymbol{\alpha}+\boldsymbol{\beta} \mathbf{X}+\mathbf{e}
$$

\section{Keterangan:}

$$
\begin{array}{ll}
\mathrm{Y} & =\text { Return Saham } \\
\alpha & =\text { Konstanta } \\
\mathrm{X}_{1} & =\text { Modal Kerja } \\
\mathrm{e} & =\text { Error atau penyimpangan yang mungkin } \\
\text { terjadi } & \mathrm{b}_{1,} \mathrm{~b}_{2},=\text { Koefisien regresi dari variabel } \mathrm{X}_{1} \text { dan } \\
\mathrm{X}_{2} &
\end{array}
$$

\section{HASIL DAN PEMBAHASAN}

\section{Uji Parsial (Uji T)}

Uji $\mathrm{t}$ dilakukan untuk mengetahui ada tidaknya pengaruh secara parsial variabel independen terhadap variabel dependen. Adapun tingkat signifikansi yang digunakan sebesar 0,05. Jika probabilitas $<0,05$ maka variabel independen secara parsial mempunyai pengaruh signifikan terhadap variabel dependen. 


\section{Hasil Uji t}

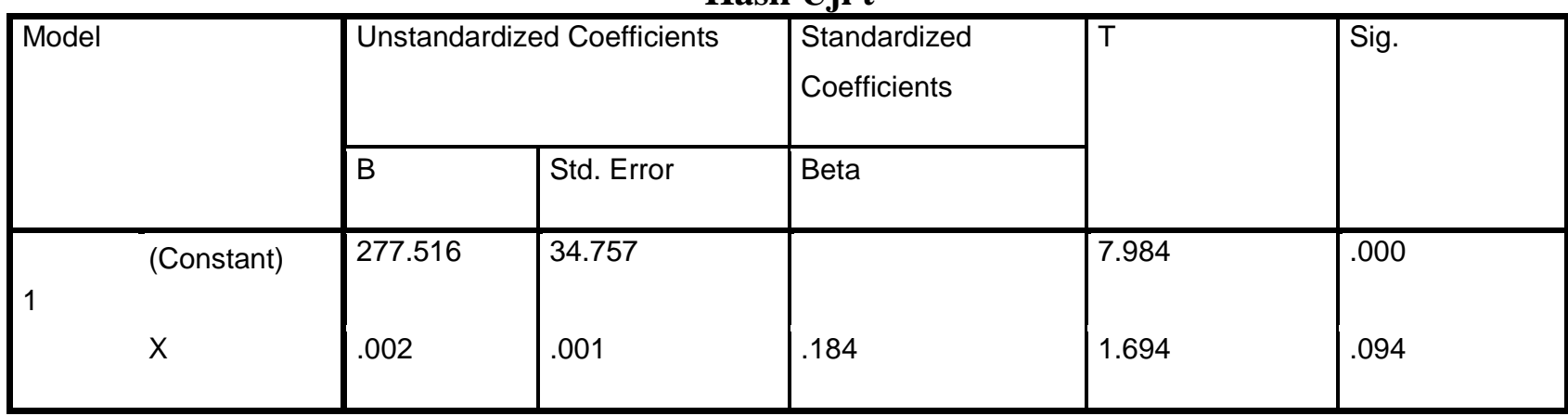

a. Dependent Variable: Y

Sumber: Output SPSS 21.0, 2017

Nilai $t_{\text {hitung }}$ pada variabel modal kerja $(\mathrm{X})$ menunjukkan nilai $t$ hitung sebesar 1,694 koefisien regresi sebesar 0.002 dan nilai probabilitas (sig) sebesar 0,094 yang lebih besar dari 0,05 hal ini berarti bahwa $\mathrm{H}_{1}$ ditolak dan $\mathrm{H}_{0}$ diterima dengan kata lain modal kerja Berpengaruh Terhadap return saham.

\section{PEMBAHASAN HASIL PENELITIAN}

Berdasarkan hasil linear sederhana diketahui tingkat signifikan untuk masing-masing variabel tersebut yaitu nilai $t_{\text {hitung }}$ pada variable Modal Kerja (X) menunjukkan nilai t hitung sebesar 1,694 koefisien regresi sebesar 0.002 dan nilai probabilitas (sig) sebesar 0,094 yang lebih besar dari 0,05 hal ini berarti bahwa $\mathrm{H}_{1}$ ditolak dan $\mathrm{H}_{0}$ diterima dengan kata lain modal kerja Berpengaruh Terhadap return saham.

\section{SIMPULAN DAN SARAN}

Berdasarkan pengujian hipotesis tentang pengaruh modal kerja terhadap return saham pada 12 perusahaan yang terdaftar di bursa efek indonesia maka dapat disimpulkan sebagai berikut:

Hasil koefisien modal kerja sebesar 0.184 nilai $\mathrm{t}$ hitung sebesar 1.694 dan tingkat signifikan sebesar 0.094.Lebih kecil dari 0.05.sehingga dapat disimpulkan modal kerja berpengaruh positif dan signifikan terhadap return saham. oleh karna itu hipotesis yang menyatakan bahwa modal kerja berpengaruh positif dan signifikan terhadap return saham diterima.

\section{SARAN}

Berdasarkan hasil pembahasan dan simpulan yang diperoleh dalam penelitian ini, dapat diberikan saran sebagai berikut:

pengaruh modal kerja terhadap return saham pada perusahaan tekstil dan germent yang terdaftar di bursa efek indonesia, berdasarkan hasil pembahasan dan pengujian statistik di dapat hasil tingkat pengembalian saham di pengaruhi oleh modal kerja suatu perusahaan. oleh karena itu untuk memperoleh investor yang memadai dengan tingkat pengembalian saham yang tinggi maka perusahaan perlu mempertimbangkan biaya modal kerja karna menjadi pertimbangan untuk memaksimalkan nilai perusahaan dan agar dapat mengambil keputusan yang tepat dalam berinvestasi

\section{DAFTAR PUSTAKA}

Anoraga, Pandji dan Piji Pakarti. 2006. Pengantar Pasar Modal. PT Rineka Cipta. Jakarta.

Darmadji \& Fakhruddin. 2011. Pasar Modal di Indonesia .edisi 3. Salemba Empat, Jakarta.

Drs. S. Munawir.(2010).Analisa Laporan Keuangan.Yogyakarta:Liberty.

Fakhruddin.2011. "Pasar Modal Indonesia". Edisi Ketiga. Jakarta : Salemba Empat.

Ghozali.2012. "Aplikasi Analisis Multivariate dengan Program IBM SPSS". Yogyakarta: Universitas Diponegoro.

Horne, James C. Van dan John M Wachowicz, Jr. 2009. "Prinsip-prinsip Manajemen Keuangan "Jakarta : $\quad$ Salemba Empat.(Edisi 13).

Jogianto, Hartono.2003.Teori Portofollio dan Analisis Investasi, Edisi kelima.

Yogyakarta: BPEE

2008.Pasar Efisien secara Keputusan. Jakarta: PT Gramedia Pustaka Utama. 
.2009.Sistem

Informasi.Yogyakarta

2010.Analisis dan Desain

Sistem Informasi, Edisi IV, Andi

Offset, Yogyakarta. .2011. Metodologi Penelitian

Bisnis: Salah Kaprah dan

Pengalaman-pengalaman.BPFE.

Yogyakarta.

MachadiAnggiNur. 2010. PerputaranKas Dan

PiutangPada

Perusahaan

Manufakturdi BEI. Jakarta

Munawir.2010.Analisa

Laporan

Keuangan.Yogyakarta:Liberty.

Prabawa, D. W, Astuti, F.2015. Manajemen Modal KerjaTerhadap Returnpada Bursa Efek Indonesia. Jakarta.

Prasetya,

$\mathrm{H}$.

$\mathrm{T}$.

2005.ReturnSahampadaIndustriMakan andanMinuman di Bursa Efek Indonesia. Jakarta.

Riyanto.2011.

ManajemenKeuangandanteori. Yogyak arta, BPFE Yogyakarta.

Suryati. 2015.Modal Kerja Dan Ukuran Perusahaan pada Bursa Efek Indonesia. Jakarta.

Supriyanto.2010.pengaruh Corporate Govemancedanbentukkepemilikanterh adapkinerjakeuangan Bank di Indonesia.Disertasi UGM Jogjakarta.

Samsul, Mohammad. 2008. Pasar Modal danManajemenPortofolio. Jakarta: Erlangga.

Sutrisno, Edi. 2009. Manajemen Sumber Daya Manusia Edisi pertama. Jakarta: Kencana Prenada Media Group.

Sugiyono.2009.Metode Penelitian Kuantitatif, Kualitatifdan R\&D, Bandung :

Alfabeta.

2010.Metode Penelitian Pendidikan Pendekatan Kuantitatif, kualitatif, dan R\&D. Bandung: Alfabeta

SarbaPriya.2012. Tingkat Profitabilitas Perusahaan. Jakarta.

Syafri, H. S (2011), Teori Akuntansi Edisi Revisi 2011. Jakarta: Rajawali Pers.

Tandelilin, Eduardus.2010. Portofolio dan Investasi Teori dan Aplikasi. Edisi pertama.Yogyakarta : Kanisius
Hornedan wachowicz.2009.TigkatKelebihan Asset Lancar. Yogyakarta. 